\title{
Who Files for Personal Bankruptcy in the United States?
}

by

\author{
Jonathan Fisher \\ Stanford University
}

CES 17-54

September, 2017

The research program of the Center for Economic Studies (CES) produces a wide range of economic analyses to improve the statistical programs of the U.S. Census Bureau. Many of these analyses take the form of CES research papers. The papers have not undergone the review accorded Census Bureau publications and no endorsement should be inferred. Any opinions and conclusions expressed herein are those of the author(s) and do not necessarily represent the views of the U.S. Census Bureau. All results have been reviewed to ensure that no confidential information is disclosed. Republication in whole or part must be cleared with the authors.

To obtain information about the series, see www.census.gov/ces or contact J. David Brown, Editor, Discussion Papers, U.S. Census Bureau, Center for Economic Studies 5K034A, 4600 Silver Hill Road, Washington, DC 20233, CES.Working.Papers@census.gov. To subscribe to the series, please click here. 


\begin{abstract}
Who files for bankruptcy in the United States is not well understood. Previous research relied on small samples from national surveys or a small number of states from administrative records. I use over 10 million administrative bankruptcy records linked to the 2000 Decennial Census and the 2001-2009 American Community Surveys to understand who files for personal bankruptcy. Bankruptcy filers are middle income, more likely to be divorced, more likely to be black, more likely to have terminal high school degree or some college, and more likely to be middle-aged. Bankruptcy filers are more likely to be employed than the U.S. as a whole, and they are more likely to be employed 50-52 weeks. The bankruptcy population is aging faster than the U.S. population as a whole. Lastly, using the pseudo-panels I study what happens in the years around bankruptcy. Individuals are likely to get divorced in the years before bankruptcy and then remarry. Income falls before bankruptcy and then rises after bankruptcy.
\end{abstract}

\footnotetext{
* I want to thank Tal Gross, Matt Notowidigdo, and Jialan Wang for providing the administrative bankruptcy records. Thanks to Nathaniel Johnson for research assistance. This research was carried out at a U.S. Federal Statistical Research Data Center facility. The results and conclusions of the paper are those of the author and do not indicate concurrence by the Census Bureau. These results have been screened to avoid revealing confidential data.
} 


\section{Introduction}

Most social insurance programs in the United States target fairly narrow groups with strict eligibility requirements, usually depending on income or earnings. Personal bankruptcy protection, on the other hand, is available to "any person who owes debts," 1 and 75 percent of households have debt (Bricker et al., 2014). White (1998) estimated that at least 15 percent of all households in 1992 would have experienced an increase in net worth in bankruptcy. While research has investigated the causes and consequences of filing for personal bankruptcy, the demographic profile of who files for bankruptcy is less understood. I fill this gap in the literature by exploiting the linkage of 10 million administrative personal bankruptcy records to the 2000 Decennial Census and the 2001-2011 American Community Surveys. I present basic summary statistics about who files for bankruptcy, along with the results of regressions to control for the correlation of socio-economic characteristics. The results here do not aim to determine the causes of filing for personal bankruptcy but instead provide a better understanding of the characteristics of personal bankruptcy filers.

Bankruptcy protection is part of the social insurance system. Bankruptcy is social in that it is paid for by risk-adjusted interest rates on debt (Gropp, Scholz, and White, 1997; Berkowitz and White, 2004). Bankruptcy is insurance in that it provides debt forgiveness and asset protection in the face of negative events (Sullivan, Warren, and Westbrook, 2000).

Bankruptcy is an important part of social insurance system. In 2015, 795,000 consumer debtors filed for personal bankruptcy, with approximately $\$ 47$ billion of debt forgiven (U.S. Courts, 2015). Debt forgiveness amounts to an average transfer of future income equal to $\$ 59,000$ per household, not counting the interest that would have accrued had the debt not been

\footnotetext{
${ }^{1}$ Fifty-Fifth Congress, Session II, Chapter 541, Chapter 1, Section 4.
} 
forgiven. In comparison, Medicaid covered approximately 72.8 million people and spent about $\$ 461$ billion in 2013, for an average government outlay of $\$ 6,300$ per recipient (U.S. Department of Health and Human Services, 2014).

Bankruptcy provides not only a large transfer, but it has also become a more important component of the social insurance system. In 1980, there were 287,564 filings, and annual filings steadily increased until they reached over 1.5 million in 2004. After the passage of the Bankruptcy Abuse and Consumer Protection Act (BAPCPA) in 2005, bankruptcy filings decreased. Several elements of BAPCPA may have contributed to the decrease in the number of filings, namely the increase in the cost of filing for bankruptcy in attorney fees and court fees (Gross, Notowidigdo, and Wang, 2014) and the means test meant to push some debtors to the less generous chapter 13 .

Despite the large number of people filing for bankruptcy and its generous benefits, who files for personal bankruptcy is not well understood. Research that reports some demographics of bankruptcy filers often comes to different conclusions. For example, using data from 1989-1995 Fisher (2005) finds that mean income in 1991 dollars is about $\$ 32,000$, while Sullivan, Warren, and Westbrook (2000) use filers from 1991 and find mean income just about \$20,000. Fisher (2005) finds that 44 percent of filers are terminal high school graduates while Sullivan et al. (2000) find only 32 percent of filers with a terminal high school degree. Emmons and Ricketts (2016) study the demography of loan delinquency, but bankruptcy and delinquency comprise two different groups. Households do not need to be delinquent on debt in order to file for bankruptcy, and some households will be delinquent but never file for bankruptcy.

Part of the reason for the lack of information and the lack of agreement is the lack of a suitable data set with bankruptcy information. Bankruptcy in a given year is a low probability 
event and is underreported in surveys, resulting in small samples of bankruptcy filers in national surveys. Sullivan, Warren, and Westbrook (2000) conducted their own surveys based on public bankruptcy records, yielding small samples from a few states.

I address this lack of knowledge by matching administrative bankruptcy records from the Public Access to Court Electronic Records (PACER) system to Decennial Census and American Community Survey (ACS) data. The unique structure of the data creates a large sample of bankruptcy filers from 1994 through 2011, providing a profile of bankruptcy filers before and after the passage of BAPCPA. A key to the data linkage is that PACER bankruptcy records can be linked with that person's information in the 2000 Decennial or any year of the ACS. In other words, I do not need to observe the person in the bankruptcy record in the same year as they appear in the Census Bureau data. The results here provide a more nuanced and deeper understanding of who files for bankruptcy.

\section{Personal Bankruptcy in the United States}

Personal bankruptcy is divided into two chapters, 7 and 13. Chapter 7 bankruptcy forgives most unsecured debts with no need to pay money to creditors. Secured debts are discharged only if the filer forfeits the collateral. The filer forfeits assets exceeding the state-determined exemption level. As shown below, almost all chapter 7 filers have zero non-exempt assets.

Chapter 13 is designed for regular wage earners but is used almost exclusively by those who would lose assets under chapter 7. Chapter 13 filers do not turn over any assets to the bankruptcy court but instead propose a multi-year repayment plan for a portion of the outstanding debts. If the repayment plan is successfully completed, the filer receives a discharge of unsecured debts, similar to what would have been forgiven under chapter 7 . 
In the two years before the passage of BAPCPA, approximately $71 \%$ of filings were under chapter 7. Before BAPCPA, individuals could choose whether to file under chapter 7 or chapter 13. Among other changes, BAPCPA developed a means test, forcing any filer with income above the state mean in income, less certain expenses, to file under chapter 13. Despite these changes, the percent of households filing under chapter 13 was back to $71 \%$ in 2009 and remained in that range until 2012. Since 2012, the percent filing under chapter 7 fell and was only $63 \%$ in 2015 . Cornwell and $\mathrm{Xu}$ (2014) find indirect evidence early in the passage of BAPCPA that filers were moved to chapter 13, but their data only go through 2007.

Two hypotheses drive research on the causes of bankruptcy - do filers experience a negative shock that leads to bankruptcy? Or are filers strategic and decide to file mainly because of a large financial benefit to filing? Fay, Hurst, and White (2002) find that an increase in the financial benefit to filing increases the likelihood of filing, and they find little support that divorce, unemployment, or a health shock affect the likelihood of filing. Sullivan, Warren, and Westbrook (2000) focus more on the negative shocks that bankruptcy filers experience, finding that job loss, sickness and injury, and divorce lead to bankruptcy. Keys (2015) finds that households are over three times more likely to file for bankruptcy in the year after job loss.

Bankruptcy filers also experience indirect costs after filing. Bankruptcy appears on credit reports for a specified number of years, and past bankruptcy filers have an increased likelihood of being denied access to credit after bankruptcy, or if they have access to credit they pay higher interest rates (Musto, 2004; Fisher and Lyons, 2010; and, Han and Li, 2011). As further evidence of credit market exclusion, the consumption of those who filed for bankruptcy in the past is excessively sensitive to predictable changes in income, most likely due to liquidity constraints (Filer and Fisher, 2007). 


\section{Linked Administrative Bankruptcy Records}

Bankruptcy filings are public records and can be accessed through the Public Access to Court Electronic Records (PACER) system, but it costs 10 cents per page to download records. Gross, Notowidigdo, and Wang (2014) petitioned for a fee waiver and were granted free access to records from 81 of the 94 federal bankruptcy districts. A script was run to scrape the records from the PACER site. The script did not yield data for all quarters for all districts. There are several holes in the data that prevent the usage of data from the 81 districts. Overall, I have a consistent sample of 72 districts from 1994-2009.

The data available from PACER includes the first and last name of the bankruptcy filer, along with the last four digits of the individual's social security number. If the filing was joint with a spouse, the same information exists for the spouse. For joint debts, both spouses need to file for bankruptcy. Otherwise, the non-filing spouse remains liable for the joint debt. The PACER file also includes the address of the filer at the time of the filing and the date of the filing.

The PACER data were provided to the U.S. Census Bureau's Center for Administrative Records Research and Applications (CARRA). With the name, address, and date of filing, staff at CARRA assigned a Protected Identification Key (PIK) to the PACER data. The PIK is Census' analogue to the social security number, a unique individual identifier. Wagner and Layne (2013) provide background on CARRA's linkage methodology.

I linked the PACER data to the 2000 Decennial Short Form and Long Form, along with the 2001-2009 American Community Surveys (ACS) via the PIK. To be linked to the Decennial or ACS, the bankruptcy does not need to occur in the same year as the individual is observed in 
the data. The race, education, and year of birth from the 2000 Decennial can be used to assign race, education, and date of birth to someone who filed for bankruptcy in any year.

For characteristics that could change over time such as marital status, income, and homeownership status, I build pseudo-cohorts. For bankruptcy filers in 2000, I use those that match to the 2000 Decennial Long Form to calculate homeownership status in the calendar year of bankruptcy, and I use bankruptcy filers in 2001 (1999) that match to the 2000 Long Form to calculate homeownership status in the calendar year before (after) filing for bankruptcy. The pseudo-bankruptcy cohorts allow me to show how time-varying characteristics such as income and employment status change before and after bankruptcy.

\section{Who Files for Bankruptcy?}

In the tables and figures, I compare the population of bankruptcy filers to the U.S. population from the same states. All population figures come from Ruggles, Genadek, Goeken, Grover, and Sobek (2015). For statistics at the household level, meaning household income and homeownership status, we use all households living in the 72 bankruptcy districts in the PACER data. For statistics at the person level, we use individuals ages 21-65 as a proxy for the bankruptcy eligible population because we look at variables such as employment and disability.

\section{Income and Employment}

I begin by describing the income and employment status of bankruptcy filers in the year they filed for bankruptcy. For the Decennial, income and weeks employed refer to calendar year 1999, while employment status and self-employment status refer to 2000. Thus, I use year 1999 
bankruptcy filers for income and weeks employed but year 2000 bankruptcy filers for the percent employed and percent self-employed.

The biggest take-away is that bankruptcy filers come from the middle of the income distribution (Table 1). For filers under both bankruptcy chapters, household income at the $25^{\text {th }}$ percentile is about equal to the national $25^{\text {th }}$ percentile, with both chapter 7 and chapter 13 filers reporting about $\$ 26,400$ in income in 1999 . Median income for bankruptcy filers is $\$ 42,000$, which is $\$ 6,000$ less than the national median, and income at the $75^{\text {th }}$ percentile for filers is $\$ 63,100$, about $\$ 14,000$ below the $75^{\text {th }}$ percentile nationally. The only real difference between chapter 7 and chapter 13 filers is at the mean, with chapter 13 filers having $\$ 51,240$ in income versus $\$ 50,130$ for chapter 7 filers, while there is no difference at the $75^{\text {th }}$ percentile and below. The difference in the mean indicates that there are more high-income chapter 13 filers.

Until now, the conventional wisdom regarding the income of bankruptcy filers was from Sullivan, Warren, and Westbrook (2000). Their basic thesis is that bankruptcy filers are middle class, which is exactly what I find here for income. In fact, my results more strongly support their hypothesis that bankruptcy filers are middle income, as median income of bankruptcy filers is just $\$ 6,000$ below the national median. Sullivan, Warren, and Westbrook (2000), on the other hand, find that median income of their bankruptcy filers is about half of the median.

I would expect to see a larger difference in the income of chapter 7 and chapter 13 filers in the 2008-2009 ACS, as this was after the passage of BAPCPA in 2005. The means test in BAPCPA is designed to force households with income above the state median into chapter 13 . However, the means test allows households to subtract some spending to help households avoid the means test. Table 1 shows that at least up to the $75^{\text {th }}$ percentile, chapter 7 and chapter 13 filers have similar household income in the year of filing even after BAPCPA. If the BAPCPA 
means test had an effect, it seems to be among some high-income households that could not use expenses to circumvent the means test. Mean income among chapter 13 filers is $\$ 50,300$ postBAPCPA, while mean income for chapter 7 filers is only $\$ 43,500$ (Table 1). There is a larger difference between mean income between chapter 7 and chapter 13 filers after BAPCPA.

Turning to employment status, a higher percentage of bankruptcy filers were employed, and bankruptcy filers were more likely to be employed 50-52 weeks, when compared to national averages. Only 72.9 percent of adults in the U.S. were employed in 2000 , while 74.7 percent of chapter 7 filers were employed and 76.0 percent of chapter 13 filers (Table 1). Over 60 percent of bankruptcy filers were employed 50-52 weeks in the year of bankruptcy, compared to 58 percent nationally. Post-BAPCPA, chapter 7 filers look more like the national averages than they did in 2000. But chapter 13 filers remain more likely to employed and employed 50-52 weeks compared to national averages. The one difference post-BAPCPA is between chapter 7 and chapter 13 filers, with 80.5 percent of chapter 13 filers employed compared to 73.8 percent of chapter 7 filers. In addition, a higher percentage of chapter 13 filers were employed 50-52 weeks in the year of bankruptcy. Both of these employment-related facts are consistent with the design of BAPCPA.

An interesting new fact established here is that in 2000, 6.3 percent of chapter 7 filers reported being self-employed in the year of their bankruptcy, and 7.0 percent of chapter 13 filers were self-employed, compared to a national average of 8.4 percent. The percent of bankruptcy filers self-employed was less than the national average in 2000 but more than the national average in 2008 and 2009, with about 9.8 percent of filers self-employed. It is not clear that this change in the percent self-employed could be driven by changes in BAPCPA. 
Overall on income and employment, there is little difference between chapter 7 and chapter 13 filers, despite the fact that chapter 13 was designed for regular wage earners. Income and employment status do not seem to be important factors affecting the bankruptcy chapter chosen, except for some high-income earners post-BAPCPA. This indicates that the highest income households that want to file for bankruptcy were being forced to chapter 13 under BAPCPA, suggesting that the means test had some effect on chapter choice.

\section{Demographic Characteristics}

Now I turn to demographic characteristics to understand the types of individuals that file for bankruptcy. Table 2 starts with the race, ethnicity, and education of bankruptcy filers. In 2000, white non-Hispanics and Hispanics are under-represented in bankruptcy, while black nonHispanics make up 10.5 percent of the U.S. but 22.0 percent of bankruptcy filers. Sullivan, Warren, and Westbrook (2000) also find that black individuals are over-represented in bankruptcy, but they also find that white individuals are over-represented, which I do not find.

After the passage of BAPCA, the racial composition of bankruptcy filers is considerably closer to the national distribution than what was seen in 2000, with blacks still over-represented in bankruptcy but by a much smaller margin than seen in 2000. It is not clear what part of BAPCPA could have led to this change in the racial composition of bankruptcy filers.

For education, over 70 percent of bankruptcy filers had terminal high school degrees or some college in 2000 , while only 58 percent of the U.S. as a whole had those levels of education. College graduates are under-represented in bankruptcy. The education results seem consistent with the income results in that one would expect high school graduates and those with some 
college to be more likely to be in the middle of the income distribution than those with less or more education.

Table 3 presents additional demographic statistics, separating by bankruptcy chapter, starting with marital status. I observe large differences in marital status between chapter 7 and chapter 13 filers, and filers are different than the adult population as a whole. Bankruptcy filers are less likely to be married or single and more likely to be divorced, separated, or widowed. Divorce has been posited as one potential negative shock that leads to bankruptcy (Sullivan, Warren, and Westbrook, 2000), and my results support that supposition. However, Fisher and Lyons (2006) investigated the relationship between divorce and bankruptcy and found that there is a correlation between the two but that the relationship does not appear causal in either direction.

Table 3 also shows that a higher percentage of chapter 7 filers are not married, with 48 percent of chapter 7 filers not married. The pattern of fewer non-married filing under chapter 7 is likely explained in part by the non-married having fewer assets than the married (Federal Reserve Board, 2014), as those with assets to protect are more likely to file under chapter 13.

Becoming disabled is another negative shock that may affect bankruptcy, and Table 3 shows that 25-26 percent of bankruptcy filers report some kind of disability, which is more than 10 percentage points higher than the national average. Again, these results do not prove a causal relationship but instead show that a higher fraction of bankruptcy filers are disabled.

Next I turn to homeownership status and whether the individual has moved at least once in the last five years. Chapter 7 filers are less likely to own a home than chapter 13 filers and less than the national average, with 62.9 percent of chapter 7 filers living in an owned home (Table 3). Chapter 7 filers are also more likely to have moved in the last five years when 
compared to the national average and to chapter 13 filers. Chapter 13 filers, on the other hand, are more likely to own their own home, with almost 80 percent owning, and they are less likely to have moved within the last five years. The home ownership statistics conform to the common understanding that homeowners are more likely to use chapter 13 in order to keep their home.

Highlighting the importance of keeping your home and other assets, the PACER data indicate whether the bankruptcy filer has non-exempt assets, meaning assets that may have to be forfeited under chapter 7. Only 5 percent of chapter 7 filers have non-exempt assets, while 99.7 percent of chapter 13 filers have non-exempt assets (Table 3). Thus, the most important determinant of filing under chapter 13 is not related to income or employment, but exempt assets.

Lastly, we present two statistics not generally reported in the bankruptcy literature, veteran status and immigration status. Veterans are over-represented among the bankruptcy population, with 14.7 percent of chapter 7 filers and 15.0 percent of chapter 13 filers being veterans, compared to just 10.3 percent of the national population. Angrist, Chen, and Song (2011) find that there are short-term losses in earnings for Vietnam era veterans, among those employed, amounting to 15 percent lower earnings during the 1970s and 10 percent lower earnings during the 1980s. Fitzgerald (2006) finds that veterans also have lower net worth. Veterans that served three years in the military had 14 percent lower net worth in the $50 \mathrm{~s}$, compared to non-veterans. In a study of Iraq and Afghanistan veterans, Elbogen, Johnson, Wagner, Newton, and Beckham (2012) find that 9.6 percent of their sample had more than $\$ 40,000$ in debt. Thus, veteran's over-representation in bankruptcy could potentially be explained by lower earnings, higher debt, and lower net worth. 
Fewer immigrants are found among the bankruptcy population. Only 8.6 percent of chapter 7 filers are immigrants, while 15.3 percent of the U.S. population is immigrants. Their lower representation may be related to several factors, including lack of information regarding the benefits of filing for bankruptcy in the U.S. (Fisher, 2017). Bankruptcy law in other countries is less pro-debtor (White, 2007), including some countries not allowing bankruptcy for consumer debtors. Because immigrants may not be familiar with the U.S. bankruptcy system, they may be less likely to file for bankruptcy.

\section{Age Distribution}

The last demographic characteristic I focus on is the age distribution of bankruptcy filers. I expect a life-cycle pattern to the age distribution, with fewer younger and fewer older filers (Agarwal, Chomsisengphet, and Liu, 2011). Younger adults have not had as much time to accumulate debt, while older adults are more likely to have significant assets that would be lost in bankruptcy.

Figure 1 shows the distribution of age for bankruptcy filers in 2000. Only 5 percent of bankruptcy filers are younger than age 25 . Then we see a sharp increase, with the peak ages for filing being from ages 40-44. Fifty-eight percent of bankruptcy filers are ages $30-49$, consistent with a life-cycle relationship. Median debt is highest for 35-44 year olds and 45-54 year olds (Federal Reserve Board, 2014), matching the pattern in bankruptcy patterns by age as well.

Figure 2 expands the horizon to look at the age distribution from 1996 through 2011. Rather than present raw percentages, the percentages are divided by the percent of the national population within the same age range. Thus, a value of less than one indicates that the age range is under-represented in bankruptcy, and a value larger than one indicates that the age range is 
over-represented. In 1996, 20-24 year olds have a value of 0.51 , indicating that there were $49 \%$ fewer 20-24 year old bankruptcy filers than 20-24 year olds in the population as a whole. Because the U.S. population is getting older from 1994-2011, this adjustment allows me to separate out the effect of the aging population on the bankruptcy filing population.

The bankruptcy population is growing older at a rate faster than the population as a whole (Figure 2). Those ages 55-59 and ages 60-64 were under-represented in 1996 but overrepresented in 2011, such that 55-59 year olds in 2011 filed at a rate similar to 45-49 year olds in 2000. At younger ages, 25-29 year olds and 30-34 year olds did the opposite, going from overrepresented to under-represented between 1996 and 2011. That financial difficulty is persisting to older ages suggests that these younger cohorts will be less prepared for retirement than older cohorts. These bankruptcy results match the debt patterns among older adults found in Lusardi, Mitchell, and Oggero (2017). Younger cohorts of 56-61 year olds hold more debt and have higher debt-to-assets than older cohorts, suggesting the type of greater financial vulnerability that could lead to increased bankruptcy filings.

\section{Income and Employment in the Years Around Bankruptcy}

Another way to view the socio-economic characteristics of bankruptcy filers is to follow the changes in those variables in the years before and after bankruptcy. In this way, I can identify changes in variables that might contribute to the need to file for bankruptcy. The analysis in this paper is not causal but instead presents correlations.

The results show the results in the four years before and four years after bankruptcy. One caveat is that the filers are not the same cohort. The employment rate for someone four years before bankruptcy is the 2000 employment rate for those who filed for bankruptcy in 2004, and 
the employment rate for someone four years after bankruptcy is the 2000 employment rate for those who filed for bankruptcy in 1996. One advantage of this approach is that I do not need to worry about different macroeconomic conditions because all of the employment rates are from the same year. One disadvantage is that the individuals one year before bankruptcy are not the same from the same cohort of bankruptcy filers as the individuals one year after bankruptcy.

Employment rates decline continuously for chapter 7 and chapter 13 filers before and after bankruptcy, with 77 percent employed four years before bankruptcy and 73 percent of chapter 7 filers employed four years after bankruptcy (Figure 3). The decline in the employment rate is smaller for chapter 13 filers, as would be expected because chapter 13 filers need to continue to repay the debt in the years after the filing. But even for chapter 13 filers the percent employed falls from 77.9 percent to 75.2 percent. While there is a declining employment rate, it is important to remember that bankruptcy filers are still more likely to be employed, even four years after filing for bankruptcy, than the population as a whole (Table 1). The evidence here matches Hong and Li (2007) that find a negative but statistically insignificant effect of a past bankruptcy on hours worked.

As comparison, Herkenhoff, Phillips, and Cohen-Cole (2016) study past bankruptcy filers from credit reports and find that about $81 \%$ of past bankruptcy filers are employed. Their definition of employment is broader than the one I use, which likely explains the difference. They count anyone as employed if the person had at least $\$ 1,000$ in income from employment or self-employment in a given year. Herkenhoff et al. (2016) also focus on how the removal of the bankruptcy flag from the credit report affects non-employment and find that non-employment declines by 0.7 percent after the bankruptcy flag is removed from the credit report. Their results suggest that the post-bankruptcy decline in employment observed in Figure 3 is due to a 
bankruptcy flag appearing on the credit report. Their results suggest that employers are less likely to hire past bankruptcy filers by completing a credit check before hiring.

The pattern for weeks worked differs from the pattern for employment. The percent of bankruptcy filers who are employed 50-52 weeks falls from four years before bankruptcy until the year of bankruptcy, from 62.3 percent to 60.2 percent for chapter 7 filers (Figure 3). In the years after bankruptcy, the percent of chapter 7 filers employed 50-52 weeks increases to around 62 percent. A similar pattern is seen for chapter 13 filers.

Putting the employed results with the weeks worked, fewer bankruptcy filers are employed after bankruptcy but among those that are still working, they return to working 50-52 weeks per year. Overall, there is suggestive evidence that employment shocks may contribute to filing for bankruptcy, but it still remains that the majority of bankruptcy filers are employed and employed 50-52 weeks per year.

Self-employment rates follow a u-shaped pattern, with a decrease in self-employment rates in the years before bankruptcy and a commensurate increase in self-employment rates after bankruptcy (Figure 3). The results could suggest that the self-employed are filing because their business failed, but I cannot rule out that the self-employed were contractors who then became employees at a company. Panel data would be needed to understand more about selfemployment.

Herkenhoff et al. (2016) find that the 7-8 percent of post-bankruptcy filers are selfemployed, right in line with the findings in Figure 3. They also find that the removal of the bankruptcy flag increases the likelihood of someone becoming self-employed, which matches the result in Table 4 that self-employment increases after a bankruptcy filing. 
Turning to income tells us whether the job loss or decrease in weeks worked affects total household income. Mean income falls by four percent for chapter 7 filers in the four years before bankruptcy, and mean income falls by 8 percent for chapter 13 filers (Figure 3). Dobbie and Song (2015) link the same bankruptcy data as I use here to Social Security Administration earnings records. They find no change in mean earnings in the four years before chapter 13 bankruptcy. The difference could be that they use individual earnings and not household income.

After bankruptcy, income returns to levels seen before bankruptcy, suggesting a temporary negative income shock may have contributed to the bankruptcy decision. Dobbie and Song (2015) also find an increase in earnings in the first few years after filing for chapter 13.

\section{Demographics in the Years Around Bankruptcy}

Next I turn to analyzing changes in demographic characteristics around bankruptcy, focusing on marital status and housing tenure. The consistent pattern in Figure 4 is that the percent of individuals who report being divorced, widowed, or separated increases in the years leading up to bankruptcy, from 24.2 percent four years before bankruptcy to 30.3 percent in the year of bankruptcy. The percent married falls and then rises, indicating a churning between married and divorced, widowed, or separated. Someone may divorce three years before bankruptcy but be remarried by the time of the bankruptcy filing.

Homeownership for chapter 7 filers is relatively flat in the years before bankruptcy, while homeownership increases in the years after filing for chapter 7 (Figure 4). The homeownership result for chapter 7 filers indicates that filing for bankruptcy helps the households achieve homeownership, possibly by forgiving unsecured debt that may have prevented these households from obtaining a mortgage. Because the mortgage is secured by the home, bankruptcy filers may 
be less affected in their ability to obtain a mortgage in the years after bankruptcy, though Fisher and Lyons (2010) find that bankruptcy filers pay a higher interest rate on the mortgage.

The pattern of homeownership is different for chapter 13 filers. One benefit of chapter 13 is that it allows filers to retain their home even if they have significant equity in it. However, a lower percentage of chapter 13 filer own their home in the first few years after bankruptcy (Figure 4). It is impossible to know whether the observed pattern in Figure 4 is a cohort effect that chapter 13 filers in 1999 happened to be less likely to own a home than chapter 13 filers in 2000.

\section{Regression results}

The last analysis explores the correlations described above in more detail by seeing which correlations remain strong after controlling for the other socio-economic characteristics. The first two models in Table 4 identify the correlates of the bankruptcy decision, with the second model including state fixed effects. The third model looks at the correlates of the choice between filing for bankruptcy under chapter 7 versus chapter 13, with the dependent variable equaling one if the household filed under chapter7 and zero if filed under chapter 13. The last model excludes the non-filers.

All of the patterns seen in the tables above persist in the regression analysis. The two variables with the largest coefficients are for black individuals and for those divorced, widowed,

or separated, matching the results from Table 2 and Table 3 . As seen in Table 1, those currently employed are more likely to file for bankruptcy, while the self-employed are less likely to file. The coefficient on income is negative, and the square term is small relative to the linear term. 
The last two columns of Table 4 show the correlates with deciding to file under chapter 7. As shown in Table 1, employment and income are not as important to filing under chapter 13 as would be expected by the design of the law. Income and employment status are only weakly related to chapter choice. The biggest determinant is whether the household owned a home, with more homeowners choosing chapter 13. Domowitz and Sartain (1999) also find that homeownership predicts filing under chapter 13. Interestingly, black individuals are more likely to choose chapter 13. It is not immediately clear why black individuals would file under chapter 13, after controlling for all of the other characteristics.

\section{Conclusion}

This paper represents the first to show the full demographic profile of bankruptcy filers in the United States. I confirm some of the conventional wisdom of who files for bankruptcy. Bankruptcy filers are middle income, more likely to be divorced, more likely to be black, more likely to have terminal high school degree or some college, and more likely to be middle-aged.

I show that bankruptcy filers are middle income and that income of bankruptcy filers does not change much in the years before and after bankruptcy. Black individuals and veterans are over-represented in bankruptcy, even when controlling for socio-economic and other demographic characteristics, while immigrants are under-represented in bankruptcy.

I also establish several new facts that change our view of bankruptcy filers and in other ways deepens our understanding of bankruptcy filers. Bankruptcy filers are more likely to be employed than the U.S. as a whole, and they are more likely to be employed 50-52 weeks. Bankruptcy filers are more likely to be veterans. It is known that veterans have a higher likelihood of financial difficulty, but it was not known that these financial difficulties also 
translated into bankruptcy. Bankruptcy filers are less likely to be immigrants but more likely to be disabled.

Another important fact established here is that the bankruptcy population is aging faster than the U.S. population as a whole. Since 2004, bankruptcy filers are now over-represented among those 55-64, while that age range was under-represented in bankruptcy before 2004 .

The comparison of chapter 7 and chapter 13 filers is also new and interesting. The large samples in this paper allow me to separate filers by chapter, which is not possible in many results that use survey data, and credit report data does not include bankruptcy chapter. In economic terms, chapter 7 and chapter 13 filers are not that different, except that chapter 13 filers have assets that would be lost in a chapter 7 filing and are more likely to own a home. Otherwise, chapter 7 and chapter 13 filers have similar income distributions and about the same employment rates.

Lastly, using the pseudo-panels I am able to look at what happens in the years around bankruptcy. Individuals are likely to get divorced in the years before bankruptcy and then remarry. Income falls before bankruptcy and then rises after bankruptcy. The last interesting finding is that chapter 7 filers are much more likely to own their home four years after bankruptcy than four years before bankruptcy. It seems that the fact of filing for bankruptcy did not prevent them from obtaining a mortgage. 


\section{References}

Agarwal, S., Chomsisengphet, S., and Liu, C. (2011) Consumer Bankruptcy and Default: The Role of Individual Social Capital. Journal of Economic Psychology 32: 632-650.

Angrist, J., Chen, S., and Song, J. (2011) Long-term Consequences of Vietnam-era Conscription: New Estimates Using Social Security Data. American Economic Review 101(3): 334-338.

Berkowitz, J., and White, M. (2004) Bankruptcy and Small Firms' Access to Credit. RAND Journal of Economics. 35(1): 69-84.

Bricker, J., Dettling, L., Henriques, A., Hsu, J., Moore, K., Sabelhaus, J., Thompson, J., and Windle, R. (2014) Changes in U.S. Family Finances from 2010 to 2013: Evidence from the Survey of Consumer Finances. Federal Reserve Bulletin 100(4).

Cornwell, C., and Xu, B. (2014) Effects of BAPCPA on the Chapter Composition of Consumer Bankruptcies. Economics Letters 124, 439.442.

Dobbie, W., and Song, J. Debt Relief and Debtor Outcomes: Measuring the Effects of Consumer Bankruptcy Protection. American Economic Review 105(3): 1272-1311.

Domowitz, I., and Sartain, R. (1999) Determinants of the Consumer Bankruptcy Decision Journal of Finance 54(1): 403-420.

Elbogen, E., Johnson, S., Wagner, H., Newton, V., and Beckham, J. (2012) Financial Well-Being and Postdeployment Adjustment Among Iraq and Afghanistan War Veterans. Military Medicine 177(6): 669-675.

Fay, S., Hurst, E., and White, M. (2002) The Household Bankruptcy Decision. American Economic Review 92(3), 706-717.

Federal Reserve Board (2014) SCF Chartbook. https://www.federalreserve.gov/econresdata/scf/files/BulletinCharts.pdf Accessed December 22, 2016

Fifty-Fifth Congress, Session II, Chapter 541, Chapter 1, Section 4.

Filer, L., and Fisher, J. (2007) Do Liquidity Constraints Generate Excess Sensitivity in Consumption? New Evidence from a Sample of Post-Bankruptcy Households. Journal of Macroeconomics 29(4): 790-805.

Fisher, J. (2005) The Effect of Unemployment Benefits, Welfare Benefits, and Other Income on Personal Bankruptcy. Contemporary Economic Policy, 23(4), 483-492.

Fisher, J. (2017) Information and Program Participation: Personal Bankruptcy. Working Paper. 
Fisher, J. and Lyons, A. (2006) Till Debt Do Us Part: A Model of Divorce and Personal Bankruptcy. Review of Economics of the Household 4: 35-52.

Fisher, J. and Lyons, A. (2010) Information and Credit Access: Using Bankruptcy as a Signal. Applied Economics 42(25): 3175-3193.

Fitzgerald, K. (2006) The Effect of Military Service on Wealth Accumulation. Research on Aging 28(1): 56-83.

Gropp, R., Scholz, J., and White, M. (1997) Personal Bankruptcy and Credit Supply and Demand. Quarterly Journal of Economics 112(1): 217-251.

Gross, T., Notowidigdo, M., and Wang, J. (2014) Liquidity Constraints and Personal Bankruptcy: Evidence from Tax Rebates, Review of Economics and Statistics 96(3): 431443.

Han, S., and Li, G. (2011) Household Borrowing after Personal Bankruptcy. Journal of Money, Credit, and Banking 43(2-3): 491-517.

Herkenhoff, K., Phillips, G., Cohen-Cole, E. (2016) The Impact of Consumer Credit Access on Employment, Earnings and Entrepreneurship. NBER Working Paper 22846.

Hong, S, and Li, W., (2007) Fresh Start or Head Start? The Effects of Filing for Personal Bankruptcy on Work Effort. Journal of Financial Services Review 31: 123-152.

Keys, B. (2015) The Credit Market Consequences of Job Displacement. University of Chicago Working Paper.

Musto, D., (2004) What Happens when Evidence Leaves a Market? Evidence from Postbankruptcy Consumers. Journal of Business 77: 725-748.

Ruggles, S., Genadek, K., Goeken, R., Grover, J., and Sobek, M. Integrated Public Use Microdata Series: Version 6.0 [Machine-readable database]. Minneapolis: University of Minnesota, 2015.

Sullivan, T. A., Warren, E., and Westbrook, J. (2001) The Fragile Middle Class: Americans in Debt. New Haven, CT: Yale University Press.

U.S. Courts (2015) Bankruptcy Abuse Prevention and Consumer Protection Act Report. Retrieved from http://www.uscourts.gov/statistics-reports/bapcpa-report-2015.

U.S. Department of Health and Human Services (2014) 2014 CMS Statistics. Retrieved from https://www.cms.gov/Research-Statistics-Data-and-Systems/Statistics-Trends-andReports/CMS-Statistics-Reference-Booklet/Downloads/CMS_Stats_2014_final.pdf.

Wagner, D., and Layne, M. (2013) The Person Identification Validation System (PVS): 
Applying the Center for Administrative Records Research and Applications' (CARRA) Record Linkage Software. Census Bureau Research Report Series (\#CARRA-05-13).

White, M. (1998) Why Don't More Households File for Bankruptcy? Journal of Law, Economics, and Organization 14(2): 205-231. 
Figure 1: Age Distribution of Bankruptcy Filers in 2000

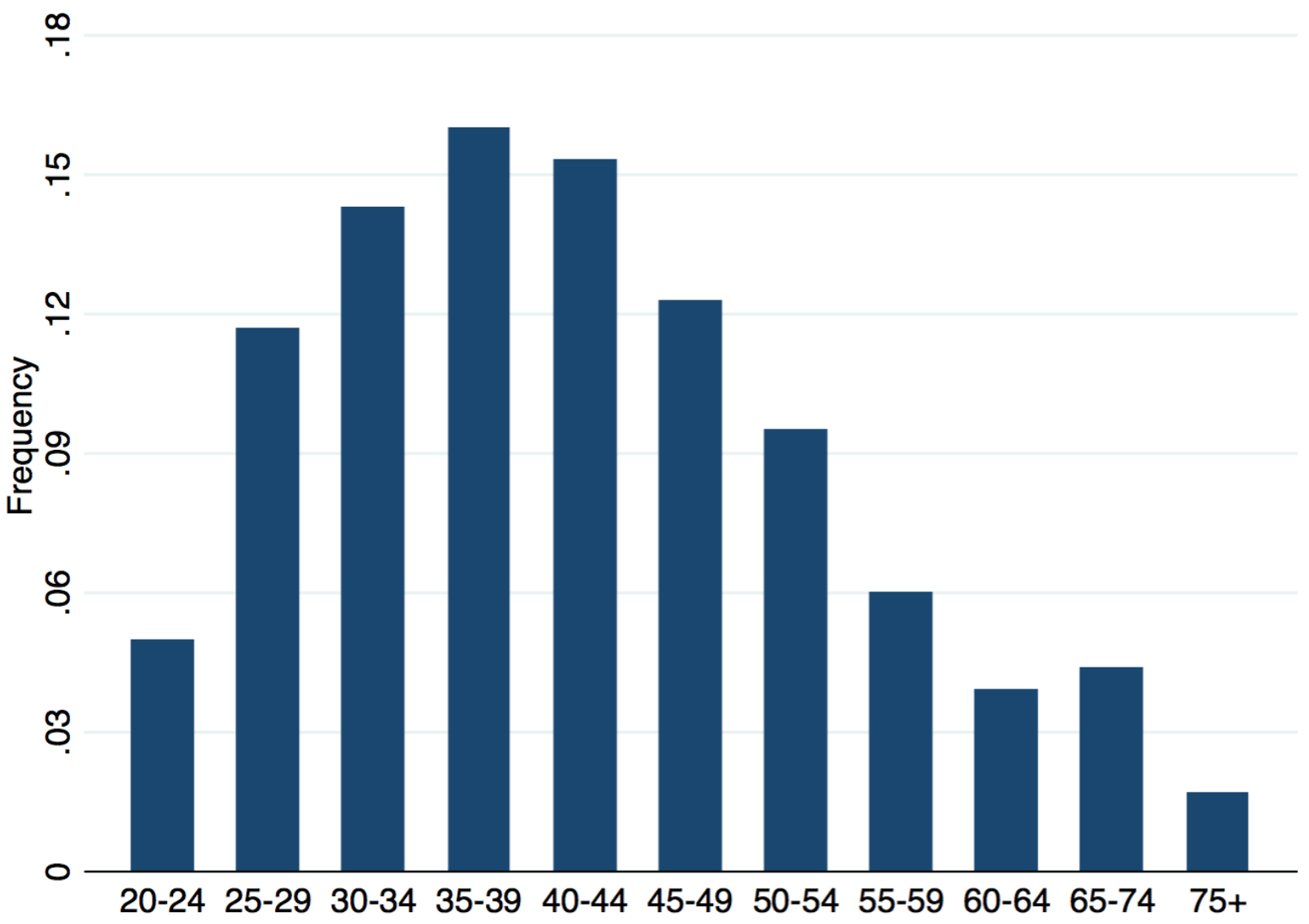

Source: PACER bankruptcy data linked to the 2000 Decennial Census and the 2001-2009 American Community Surveys 
Figure 2: Age Distribution of Bankruptcy Filers Relative to U.S. Population (1996-2011)

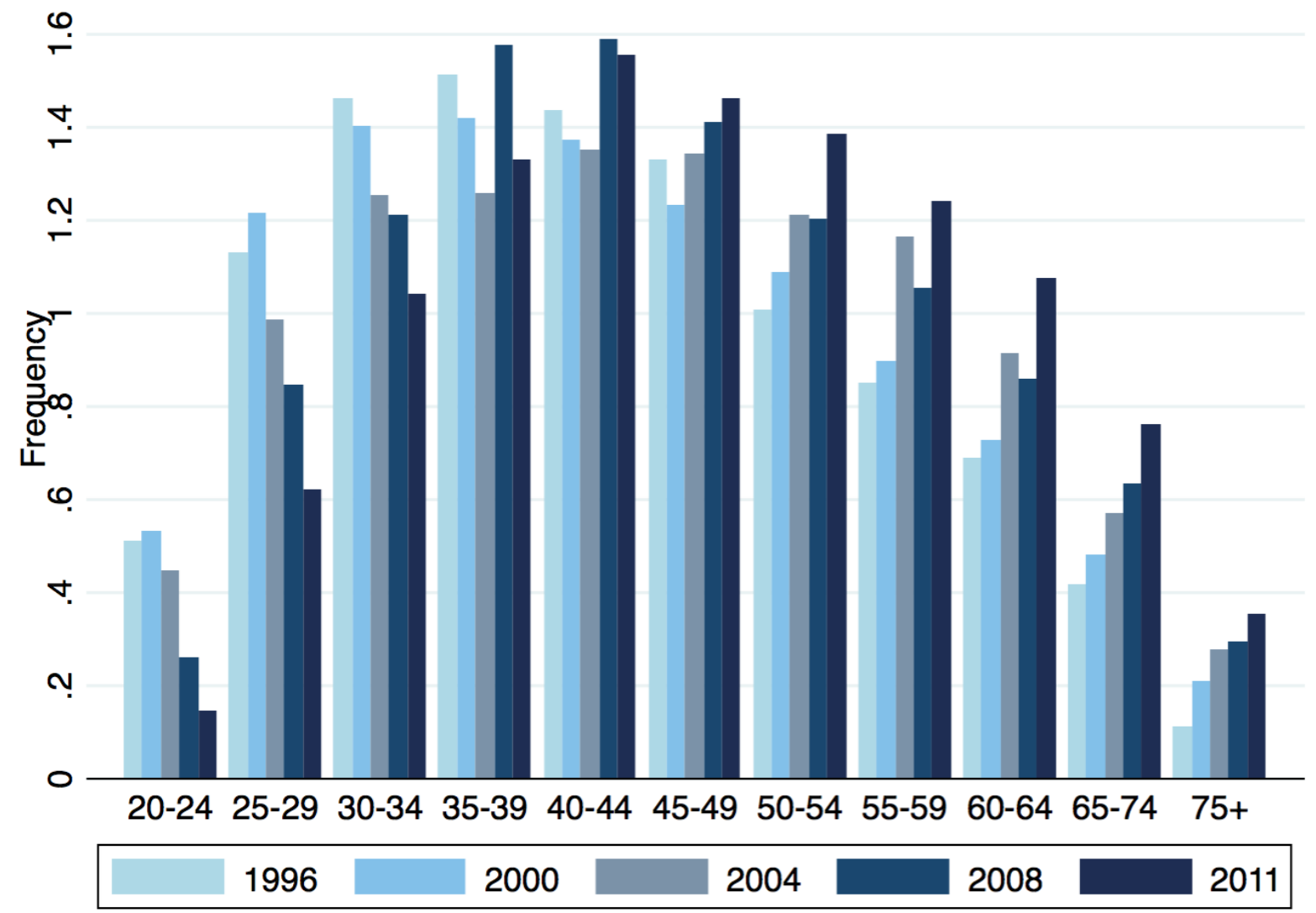

Source: PACER bankruptcy data linked to the 2000 Decennial Census and the 2001-2009 American Community Surveys

Notes: The bars represent the relative frequency of bankruptcy filers in a given age range. A value below one indicates that bankruptcy filers are less likely to be in that age range than in the population as a whole. A value above one indicates that bankruptcy filers are more likely to be in that age range than in the population as a whole. 
Figure 3: Employment and Income around Bankruptcy
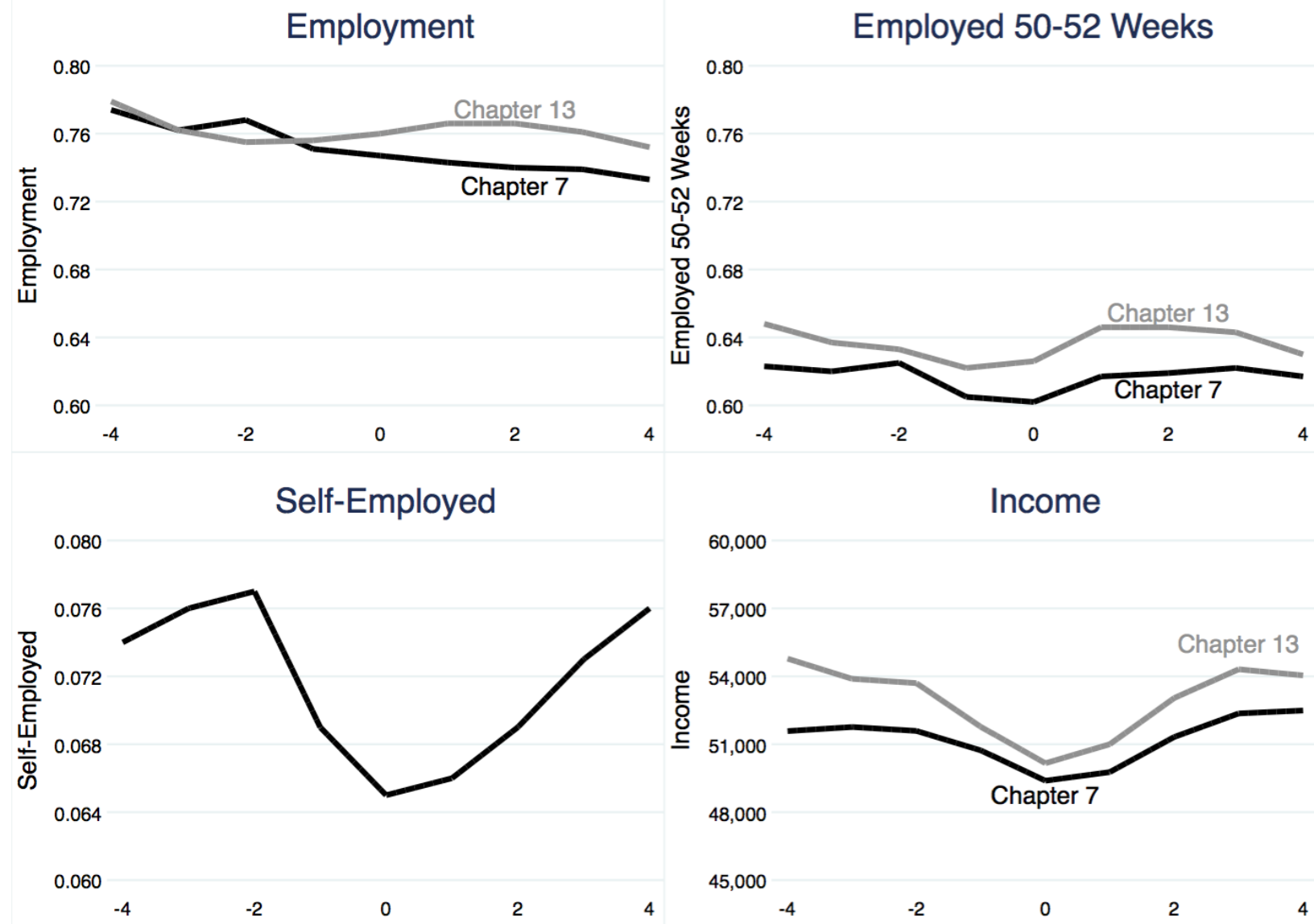

Notes: Year 0 is the year the household files for bankruptcy. Year -4 is four years before the bankruptcy filing. 
Figure 4: Marital Status and Homeownership around Bankruptcy

\section{Marital Status}

0.60
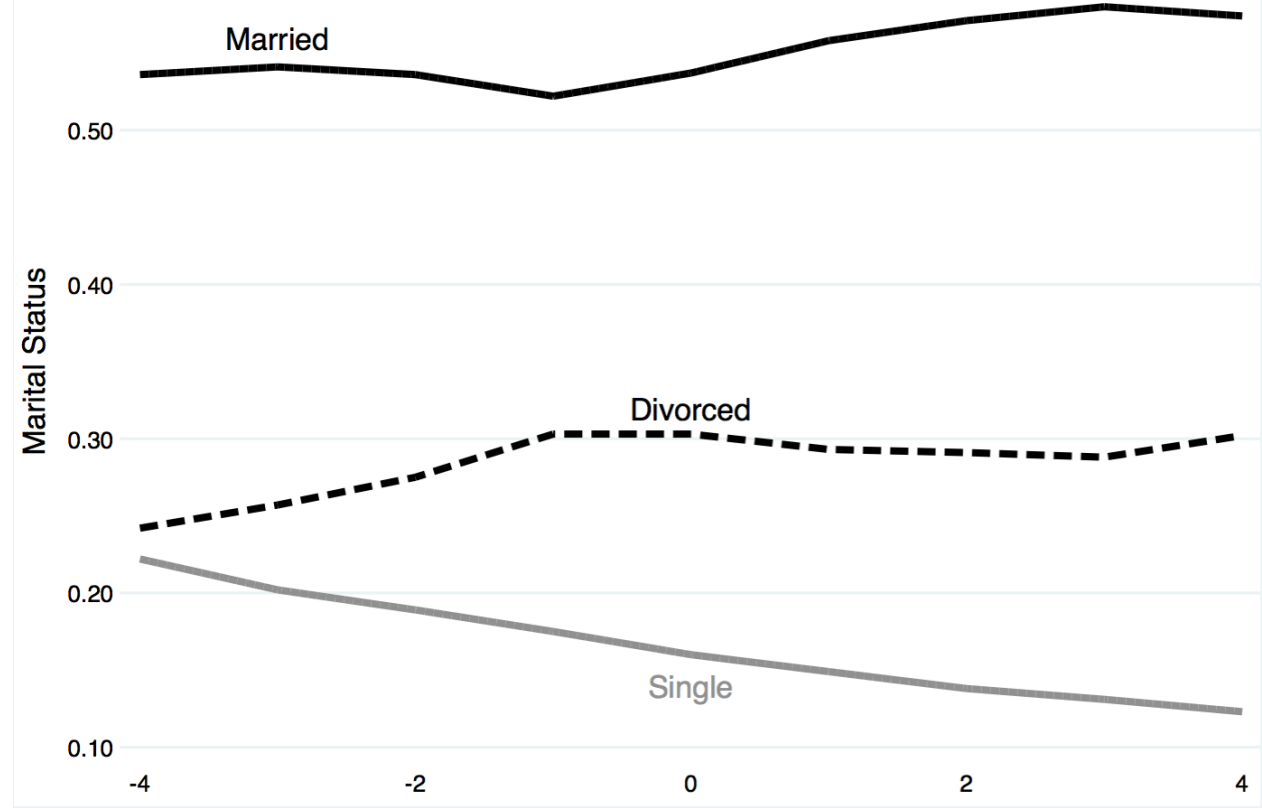

Homeownership

0.85

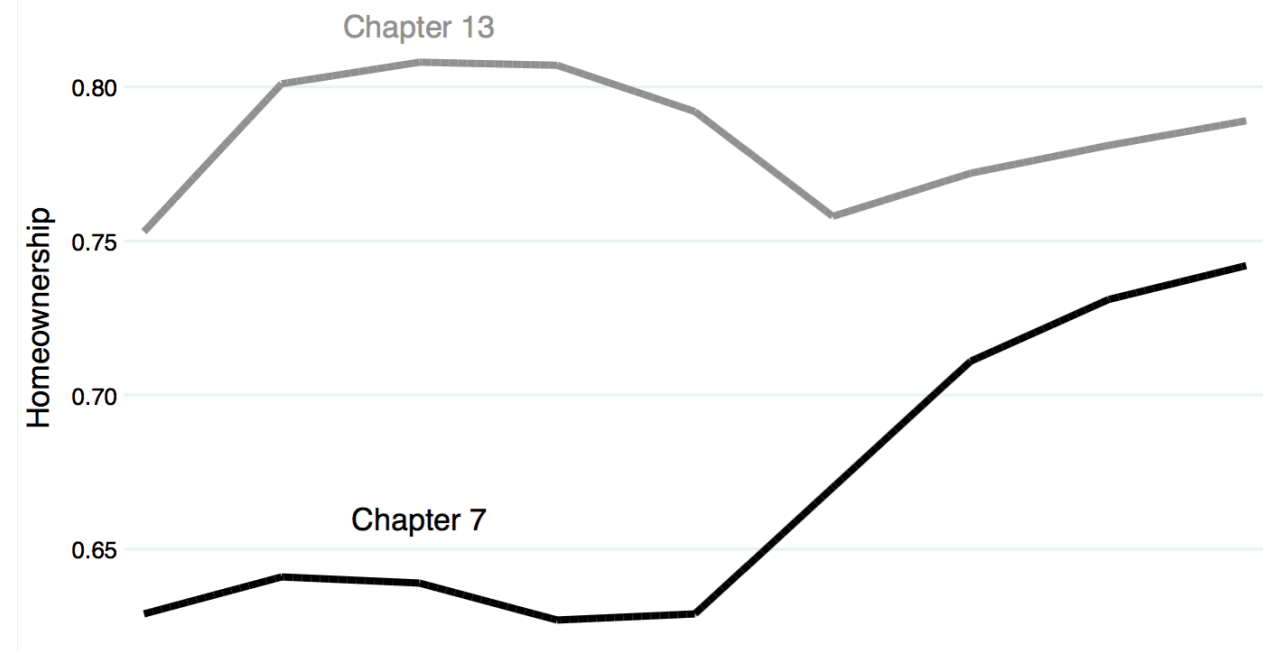

0.60

$-2$

0

2

4

Notes: Year 0 is the year the household files for bankruptcy. Year -4 is four years before the bankruptcy filing. 
Table 1: Income and Employment Statistics for Bankruptcy Filers

\begin{tabular}{lccc|ccc}
\hline & \multicolumn{3}{c|}{ 2000 Decennial } & \multicolumn{3}{c}{ 2008-2009 ACS } \\
\cline { 2 - 6 } & U.S. & Chapter 7 & Chapter 13 & U.S. & Chapter 7 & Chapter 13 \\
\hline Household Income & & & & & & \\
25th Percentile & 26,600 & 26,430 & 26,340 & 24,764 & 24,430 & 24,570 \\
50th Percentile & 48,100 & 42,080 & 42,090 & 46,510 & 39,270 & 39,460 \\
75th Percentile & 77,050 & 63,180 & 63,130 & 77,388 & 59,120 & 59,190 \\
Mean & 62,193 & 50,130 & 51,240 & 60,994 & 43,500 & 50,300 \\
& & & & & & \\
Employed & $72.9 \%$ & $74.7 \%$ & $76.0 \%$ & $73.7 \%$ & $73.8 \%$ & $80.5 \%$ \\
Employed 50-52 weeks & $57.9 \%$ & $60.2 \%$ & $62.6 \%$ & $62.2 \%$ & $61.3 \%$ & $69.7 \%$ \\
Self-employed & $8.5 \%$ & $6.3 \%$ & $7.0 \%$ & $8.5 \%$ & $9.8 \%$ & $9.7 \%$ \\
\hline
\end{tabular}

Notes: U.S. numbers derived from IPUMS USA (Ruggles et al., 2015) and are restricted to the states that also appear in the bankruptcy data. Chapter 7 and Chapter 13 numbers derived from administrative bankruptcy records linked to the 2000 Decennial Long Form and the 2008-2009 American Community Surveys (ACS). The employment statistics restrict the national population to those 21-65 year olds in IPUMS. Dollar values are in \$1999 using CPI-U-RS. 
Table 2: Race and Education: Bankruptcy Filers and Adult Population

\begin{tabular}{lcc|cc} 
& \multicolumn{2}{c}{ 2000 Decennial } & \multicolumn{2}{c}{ 2008-2009 ACS } \\
\cline { 2 - 5 } & U.S. & $\begin{array}{c}\text { Bankruptcy } \\
\text { Filers }\end{array}$ & U.S. & $\begin{array}{c}\text { Bankruptcy } \\
\text { Filers }\end{array}$ \\
\hline Race and Ethnicity & & & & \\
$\quad$ White & 70.9 & 63.8 & 67.3 & 66.8 \\
Black & 10.5 & 22.0 & 10.7 & 14.7 \\
Other race & 6.6 & 4.1 & 7.2 & 5.3 \\
$\quad$ Hispanic & 12.0 & 10.0 & 14.8 & 13.1 \\
Education & & & & \\
Less than High School & 16.2 & 16.1 & 12.6 & 17.7 \\
High School & 28.0 & 34.9 & 27.0 & 32.3 \\
Some College & 30.5 & 35.7 & 32.0 & 35.1 \\
College Plus & 25.2 & 13.2 & 28.4 & 14.9
\end{tabular}

Notes: U.S. numbers derived from IPUMS USA (Ruggles et al., 2015) and are restricted to the states that also appear in the bankruptcy data. Chapter 7 and Chapter 13 numbers derived from administrative bankruptcy records linked to the 2000 Decennial Long Form and the 2008-2009 American Community Surveys (ACS). 
Table 3: Demographics by Bankruptcy Chapter

\begin{tabular}{lcccc|ccc|} 
& \multicolumn{3}{c|}{ 2000 Decennial } & \multicolumn{3}{c|}{ 2008-2009 ACS } \\
\cline { 2 - 7 } & U.S. & Chapter 7 & Chapter 13 & U.S. & Chapter 7 & Chapter 13 \\
\hline Married & 61.9 & 52.1 & 59.3 & 56.7 & 53.5 & 64.1 \\
Divorced, Separated, or Widowed & 16.4 & 31.3 & 26.9 & 16.7 & 30.5 & 23.8 \\
Single & 21.7 & 16.6 & 13.8 & 26.6 & 16.0 & 12.1 \\
Disabled & 13.9 & 25.3 & 26.1 & 10.6 & 15.3 & 14.1 \\
Homeowner & 68.5 & 62.9 & 79.2 & 67.8 & 69.4 & 83.9 \\
Moved in Last Five/One Years & 48.2 & 54.1 & 48.4 & 15.5 & 15.1 & 8.7 \\
Exempt Assets & ---- & 5.2 & 99.7 & --- & 7.1 & 99.7 \\
Veteran & 10.3 & 14.7 & 15.0 & 7.3 & 12.3 & 15.4 \\
Immigrant & 15.3 & 8.6 & 7.1 & 17.4 & 4.4 & 3.9
\end{tabular}

Notes: U.S. numbers derived from IPUMS USA (Ruggles et al., 2015). Chapter 7 and Chapter 13 numbers derived from administrative bankruptcy records linked to the 2000 Decennial Long Form and the 2008-2009 American Community Surveys (ACS). 
Table 4: Regression Results with Bankruptcy as Outcome and Chapter 7 Filing as Outcome

\begin{tabular}{|c|c|c|c|c|c|c|}
\hline \multirow{2}{*}{ Dependent Variable } & \multicolumn{2}{|c|}{ Bankruptcy - OLS } & \multicolumn{2}{|c|}{ Bankruptcy - FE } & \multicolumn{2}{|c|}{ Chapter 7 - OLS } \\
\hline & Coefficient & $\begin{array}{c}\mathrm{t}- \\
\text { score } \\
\end{array}$ & Coefficient & $\begin{array}{c}\mathrm{t}- \\
\text { score } \\
\end{array}$ & Coefficient & $\begin{array}{c}\mathrm{t}- \\
\text { score } \\
\end{array}$ \\
\hline Employed & 0.0020 & 55.7 & 0.0021 & 57.1 & -0.0075 & -2.6 \\
\hline Self-Employed & -0.0012 & -21.7 & -0.0011 & -19.8 & -0.0190 & -4.3 \\
\hline Household Income & $-1.75 \mathrm{E}-08$ & -46.9 & $-2.00 \mathrm{E}-08$ & -48.3 & $1.60 \mathrm{E}-07$ & 3.9 \\
\hline Household Income Squared & $1.20 \mathrm{E}-14$ & 29.4 & $1.30 \mathrm{E}-14$ & 30.6 & $-2.00 \mathrm{E}-13$ & -3.1 \\
\hline Disabled & 0.0017 & 45.3 & 0.0017 & 44.2 & -0.0020 & -0.8 \\
\hline Moved in last Five Years & 0.0012 & 37.0 & 0.0012 & 35.3 & 0.0015 & 0.7 \\
\hline Divorced-Widowed-Separated & 0.0052 & 114.5 & 0.0051 & 113.1 & 0.0021 & 0.7 \\
\hline Single & -0.0001 & -1.5 & -0.0001 & -1.6 & 0.0030 & 0.8 \\
\hline Homeowner & -0.0006 & -16.7 & -0.0006 & -15.1 & -0.1364 & -54.8 \\
\hline Family Size & 0.0006 & 52.6 & 0.0006 & 51.2 & -0.0123 & -15.2 \\
\hline Immigrant & -0.0011 & -18.8 & -0.0013 & -21.4 & 0.0486 & 10.0 \\
\hline Veteran & 0.0016 & 35.3 & 0.0004 & 79.6 & -0.0075 & -2.4 \\
\hline Age & 0.0004 & 80.1 & $-5.00 \mathrm{E}-06$ & -98.2 & -0.0056 & -10.9 \\
\hline Age Squared & $-5.00 \mathrm{E}-06$ & -98.8 & 0.0016 & 35.2 & $6.40 \mathrm{E}-05$ & 11.9 \\
\hline Hispanic & -0.0003 & -3.9 & -0.0002 & -0.2 & -0.0396 & -8.0 \\
\hline Multiple Races & 0.0004 & 5.1 & 0.0002 & 3.2 & 0.007 & 1.3 \\
\hline Black & 0.0056 & 104.7 & 0.0054 & 97.6 & -0.2413 & -82.7 \\
\hline Native American & -0.0018 & -12.4 & -0.0016 & -10.6 & -0.0063 & -0.5 \\
\hline Asian & 0.0001 & 0.7 & $9.50 \mathrm{E}-06$ & 0.1 & -0.0517 & -6.2 \\
\hline High School & 0.0008 & 17.2 & 0.0008 & 17.3 & 0.0205 & 6.2 \\
\hline Some College & 0.0007 & 15.4 & 0.0007 & 15.1 & 0.0274 & 8.2 \\
\hline College-Plus & -0.0023 & -45.5 & -0.0023 & -44.7 & 0.0293 & 6.8 \\
\hline Constant & -0.0071 & -50.0 & -0.007 & -49.2 & 1.129 & 88.1 \\
\hline
\end{tabular}

Notes: The dependent variable in the first two columns is whether the household filed for bankruptcy in 2000 . It equals zero if the household did not file in 2000. The last column of results restricts the results to bankruptcy filers. The dependent variable in the last column equals one if the household filed under chapter 7, while it equals zero if they filed under chapter 13. 